\title{
ICTs in Public Administration: Geomática Gestión Y Optimización De Sistemas Research Group Case
}

\author{
Henry H. Flantrmsky, Laura Prada, Omar Gallo, and Hernán Porras
}

\begin{abstract}
ICT's can be a useful tool to improve the citizens' participation in the local government. We present, in a short introduction, the development of democracy and its models together with an analysis of the importance of technology in the democratic processes. Finally, we present some of the projects that are related to the use of new technologies in order to help more citizens to get involved in some governmental actions. Those projects we will present are in development inside our research group Geomática Gestión y Optimización de Sistemas, in the Universidad Industrial de Santander, Bucaramanga, Colombia.
\end{abstract}

\section{Index Terms-E-democracy, e-government, ICT's}

\section{INTRODUCTION}

Right now, we are living in a special time that will configure a new society inside a new world. This new world is built on the development of new ways of communication and information interchange which bring a redefinition of relationship between human beings. One of the most important changes nowadays is the concept of State due to the new relation between citizens and government. We are moving from an old conception of State, Nation-State, into a new one, Network-State, in where the framework of the power relationship has changed and they are supported on a distributed and changing base born of the informational society [1]. Therefore the democratic model must be agreed with this change and that is why it is necessary to re-think that model and provide a new democratic paradigm in which technology should play an important role. We are not playing under the same circumstances we used to do it some centuries ago when the actual democratic system began to emerge. Our technology has suffered a significant change; right now ICTs are a very important tool that helps in the democratic process all around the world since they give new forces to the old democratic tradition and make the transition to democracy more efficient. Those benefits are possible thanks to the growth in the people access to internet because these allow citizens to get more involved and more participant in the public administration.

Technology has been an important variable in the constitution of the governmental model, not just when we talk about technocratic states but in every situation in which power and control are involved to rule a country. We see how technology, in this particular case communication and

Manuscript received October 15, 2012; revised December 17, 2012.

The authors are with the research group Geomática Gestion y Optimización de Sistemas and Department of Philosophy, Universidad Industrial de Santander, Bucaramanga, Santander Colombia (e-mail: hflantrmsky@gmail.com, lorapradav@gmail.com,omga27@gmail.com, hporras@uis.edu.co). information technologies, usually begins as a hope of mass participation and deliberation, as an attempt to give the political life a new breath, but ended buried in the statu quo of elite political communication: "With the invention of the printing press and the spread of print shops throughout Europe in the late fifteenth and sixteenth centuries, a technical possibility emerged for expanding political communication that was not exclusively elite communication. But printed news and political opinion remained largely within the realm of elite communication until the mid-1700s later in many countries. Church and state supervision of printers and censorship of printing tried to keep pace with the spread of the new technology [...]Even in representative democracies with relative freedom of association and freedom of speech and the press, most political communication concerning the actions of nation-states remains elite communication." [2].

According to mentioned before and as an attempt to prevent an important misleading of the new information tools, we, at the investigation group Geomática Gestión y Optimización de Sistemas from the Universidad Industrial de Santander in Colombia, are pointing our research towards the modernization of the public administration, in order to implement digital process inside it. One of our first goals is to provide services to the regional governments in order to help them to manage their information, especially georeferential information, and to develop the needed tools to help them to use new technologies such as GIS, Cloud Computing and Crowdsourcing. We are aware of the importance that technology has in the development of society and, been an investigation group in systems management, we are concerned about the use that people will give to this new digital opportunities. In order to support this new model of participation, we are putting together the theoretical work in social sciences and the practical development with ICTs to develop a special framework for public administration.

We have been working on a couple of projects which are related to the use of new technologies in public administration, as a first step in the conceptualization of the framework mentioned above. Our goal is work together with the regional government in order to improve the way the execute some of their projects and the interaction with the people. One of those projects is concerning risk management, which is in use right now, and the other one is about monitoring the execution of infrastructure projects, which is in the development phase. The intention of the last one is to become the beginning of a bigger project about oversight of public investment on regional infrastructure.

\section{DEMOCRACY}

Democracy is one of the oldest concepts in the western 
political tradition and, at the same time, one of the most variable. In despite of the fact that in the last two thousand years have been a lot of attempts to define it, there is not yet a final concrete definition of what is a democratic government in all sense of the concept, all we have are different flavours of it. Even the definition in [3] does not give us a concrete answer to the question what is democracy: "To fix ideas, the term "democracy," [...], refers very generally to a method of group decision making characterized by a kind of equality among the participants at an essential stage of the collective decision making." But all those terms included in the mentioned definition are very wide concepts that not give us a sharp image of democracy.

Nevertheless, right now when we say "democracy" we are not mentioning the concept in general, but we are pointing out to a specific idea that could be one of the three kinds of most common democratic models: direct democracy, representative democracy and a third one, participative democracy that is a mix of those and it is based on the rational choice model, we call it too, hybrid democracy [4].

\section{A. Direct Democracy}

This first model can be understood as the ideal democracy because every citizen has an active participation in the political process, not just to choose but also deliberating about what government should do. This idea is very similar to the classic democratic model at the beginning of western civilization, but the problem with this model comes out when the population grow because there is not such an easy way, as in the ancient Athens, to call a meeting with every citizen to discuss government's issues. So, nowadays direct democracy is, at least in the classic and traditional way, a utopia.

Representative Democracy

At the other end of the democracy definition line, we found the representative democracy, in which the crowd problem has been solved reducing how much people are involved in deliberation. To avoid that, the citizens choose a group of persons who are going to make the political decision instead of them, they are called the representatives. This is the most common model today, but also has problems: mainly the increasing abyss between people's will and their representatives' interests

Movements like 15M in Spain, and others similar around the world, show that people are getting tired of these representative elite that do not represent people's interest and claim for new channels to, at least, have a voice in politics. As we can see in [5] "Democracy belongs to the people $($ demos $=$ people, krátos $=$ government $)$ which means that government is made of every one of us. However, in Spain most of the political class does not even listen to us. Politicians should be bringing our voice to the institutions, facilitating the political participation of citizens through direct channels that provide the greatest benefit to the wider society."

\section{B. Participative Democracy}

In the middle of those models appears the participative democracy that takes the direct democracy and solves the crowd problem adding a representative level without cutting out the people direct participation. We can say too that it takes the representative democracy and creates a way back to the citizens so they can make decisions about laws by means of referendums, giving them a chance of direct participation. People not make the law by themselves but they can "either accept or reject a particular proposal, usually a piece of legislation which has been passed into law by the local legislative body and signed by the pertinent executive official(s)." [6]. Nowadays this could be, maybe not the best but at least, the more efficient democratic model even though just a few countries have adopted a real participative model which embraces direct democracy, with Switzerland been at the top [7] .

TABLE I: DEMOCRATIC MODELS

\begin{tabular}{|c|c|c|c|}
\hline & $\begin{array}{l}\text { Wise Elite Model [Representative } \\
\text { democracy] }\end{array}$ & $\begin{array}{l}\text { Rational Choice Model } \\
\text { [Participative democracy] }\end{array}$ & $\begin{array}{l}\text { Deliberative Democracy Model [Direct } \\
\text { democracy] }\end{array}$ \\
\hline Definition & $\begin{array}{l}\text { People delegate decision-making to } \\
\text { a selected group through a majority } \\
\text { voting process. }\end{array}$ & $\begin{array}{l}\text { People are consumers of policies, } \\
\text { ideologies and information } \\
\text { formulated by the State and } \\
\text { politicians. }\end{array}$ & $\begin{array}{l}\text { People consume as well as generate policies, } \\
\text { ideologies and information. People get together in } \\
\text { public assembly to persuade as well as be } \\
\text { persuaded by ideas, ideologies and needs. }\end{array}$ \\
\hline Representation & Strong (key issue) & Average & Weak (almost no need for representatives) \\
\hline Deliberation & $\begin{array}{l}\text { Fast, uncommitted and restricted to a } \\
\text { small group }\end{array}$ & Fast and accessible to population & Slow and accessible to population \\
\hline People's Role & Passive & Active Selection & Active Voice \\
\hline People's Action & Vote for representative (Elite) & $\begin{array}{l}\text { Vote for policies presented by } \\
\text { representatives }\end{array}$ & $\begin{array}{l}\text { Generate suggestions and vote for policies } \\
\text { presented by representatives }\end{array}$ \\
\hline People's Interaction & None & $\begin{array}{l}\text { Almost none, maybe with the } \\
\text { representatives }\end{array}$ & 'Persuade and be persuaded' \\
\hline $\begin{array}{l}\text { Implementation Cost } \\
\text { (time and State money) }\end{array}$ & Low & Average & High \\
\hline People's supervision & Low & Average & High \\
\hline Risks & $\begin{array}{l}\text { - Elite corruption } \\
\text { - Elite bias }\end{array}$ & $\begin{array}{l}\text { - Imaginary democracy (people’s } \\
\text { votes validate Elite's desires) }\end{array}$ & $\begin{array}{l}\text { - Anarchy } \\
\text { - Overwhelming participation } \\
\text { - Biased prices }\end{array}$ \\
\hline
\end{tabular}

Those models can be putted together as seen in Table I taken from [8]. In it we can see the relation between each kind of democracy and people's involvement as well the risk that the abuse of them could cause.

\section{TECHNOLOGY AND DEMOCRACY}

No matter which democratic model we are in, technology have been always there to participate in the use and control of 
power: "political institutions have developed in mutual interplay with technological progress. For example, Aristotle's view that the influence of democracy had to be restricted to a radius of 70 kilometers because a person could not travel further than that in one day has long been rendered obsolete by technological progress." [9]. About communication, the ways and methods of knowledge and information spread constitute the base on which the democracy have been built. This influence of the communications technologies is not something new; as seen before in [2], the printing press played an important role in the establishment of the representative model three hundred years ago.

Therefore, it is undeniable the importance that technology has in our lives nowadays and, how its influence over the political aspects in our society has grown. Our democratic life has changed and we must find the way to make a better use of those new technologies to improve the democratic process. Right now, we are at the beginning of that attempt and things are not very clear, there is not a specific model for the implementation of ICTs in the governmental administration but, it doesn't mean we should not try to do it. There are many positions about the role ICTs should play in the 21-century democracy but, what it is for sure, is that we are in a very special moment in which the democracy must be re-thought and it is necessary to begin the process of research about the new possibilities that brings the ICTs inside the actual democracy and use its results in practice.

In middle 70s, we got an attempt to mix new technology (cable TV) with old democracy but this tele-vote was not a success, mainly because technology was not mature enough to improve the democracy in a qualitative way. "While the reduced organizational workload and the cost-effectiveness of online voting present opportunities to increase the frequency of voting, the resulting "push-button democracy" cannot overcome some of the long-standing limitations of direct democracy. Three main criticisms include citizen's capacity, missing deliberation, and limited personal expression." [9].

Reference [9] shows us that the implementation of digital democracy does not work as an immediate translation of analog democracy, and it is necessary to achieve some prerequisites to turn our society into an information society. After that is also necessary some others conditions of political nature as we can find in [10]. The first one are related to the technical part of the e-democracy (technological infrastructure, access to technology, accessibility, education and training) and the second about the political background that it is needed in the information society to become a real e-democracy (freedom to speech / right to privacy / access to information, privacy / identity / anonymity, trust). When the society become a real information society with a political background ready for e-democracy, at that moment, come the urgent to establish a regulatory framework that must be citizen centered.

According to above mentioned, one first step into the e-democracy, or digital democracy, is to analyze, as show in [11], "how public access to information, open discussion participation, and electronic voting can be and are supported from a technical perspective."

\section{Geomática Gestión y Optimización de Sistemas’s PROJECTS}

According to the change in the communication and information technologies and as part of the mission of the research group Geomática Gestión y Optimización de Sistemas, there are two projects which are an attempt to develop new ways of communication between citizens and some state organization. The first one is concern with the use of social networks and crowdsourcing to get enough data to build an emergency map in almost real time to provide a better assistant to those places where emergency happens, and the second one is about monitoring the progress in the execution of infrastructure projects in regional development plan.

Both of them are part of a big project that consists in the implementation of a variety of services to offer to the municipal administration in order to modernize it using cloud computing. It is not yet a full implementation of technology in democracy but it is important because begins to join the citizens with their leaders thought a digital road that will support a more organized and relevant model for e-democracy inside what is called smart cities.

\section{A. Risk and Emergencies Management System Project}

This project began two years ago with an initiative of the governor of Santander at that moment, and it was an answer for the need of an information system that could help to organize the information about the different accidents that were caused by the rain (landslides, floods, closed roads, etc.). There were a lot of events all around the department and the authorities have to deal with them fast because there were a lot of people affected. Also, it provides an information system for people who are going to travel and need to know if there are some problems with the road or place of destination. The diagram of the information flow is showed in Fig. 1.

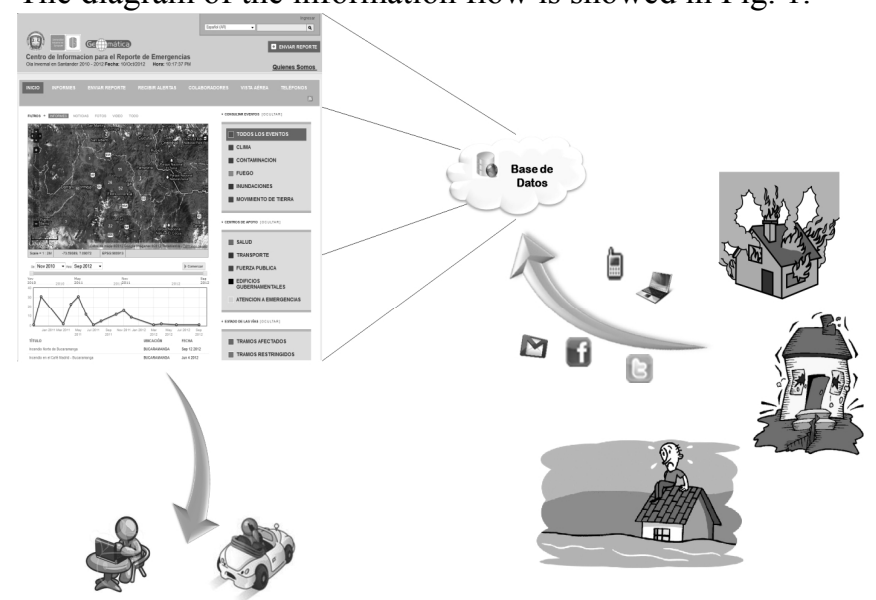

Fig. 1. Risk and emergencies management system project diagram.

The solution was founded in Ushahidi, a platform of open-sourced software "for information collection, visualization and interactive mapping." [14]. As Ushahidi website [15] says, it is "one of the few social enterprises that have, in just a few short years of existence, dramatically changed the face of how individuals and communities can influence democracy and economic development around the world." This platform made possible to order all the data and have actualized reports, almost in real time, of what was happening out there. So, the system was developed as a web 
site with a map, a list of events and a list of reports. People could send a report by the site, email or SMS, so the information was gathered thanks to community participation and the government actions were done more efficiently.

After that first successful attempt to implement new technologies for the government, in which people play an active role in the communications of their needs (specifically the accidents caused by excessive rain), the project was putted aside for the regional government but Geomática Gestión y Optimización de Sistemas kept it alive and added some other modules: one to take the census of people who were affected, and another to coordinate the delivery of helps to those people. Those modules are for internal purpose, so there is not citizen participation but, anyway, they are an improvement in governmental administration because thanks to them the process to know the real facts about the disaster was improved thanks to the information gathered by citizens themselves. Whit it, the government, or the people who are in charge, have a tool which provide accurate information to coordinate the actions needed to mitigate the damage and supply help on time. One of the most important things that this system offers, is that any person can report an incident, so the central command for emergency response are notified very quick, and the event can be controlled on time.

At the beginning this information system was an isolated initiative born from the rainy seasons in the department of Santander, but one year later the problem become national and the president of Colombia have to declare state of emergency to face the disaster. Because of that it was an urgent need to have a law that methodize and establish the line guides for attend the disasters that could came in the future. This law was enacted in April of 2012 and describes how must be the National System of Risk Disaster Administration [16], and in the fourth chapter are the characteristics the information systems must have.

What we want to remark here is that the project that was developed in the Geomática Gestión y Optimización de Sistemas group, began two years before the law was enacted so, the research has been done for a long time which give us an important background for implementing the information systems. Unfortunately, right now the project doesn't have any support from the government and remain as an internal project within the group. The website is still running and people can report when an accident happens, but because of the absence of governmental support and publicity in the media there are little traffic [17].

\section{B. Monitoring the Infrastructure Construction in Regional Government}

The second project that we mentioned is just in definition phase but development is already under way. The first objective is to create a web tool that help to control and track the execution of the infrastructure projects that are been carried out in order to accomplish the regional development plan. At the moment we are working in presenting the problem and delimiting the scope of the software. This first product would be a system supported by mobile devices as a means of supervision limited to infrastructure projects, so the users would be specific people who play the role of supervisor. But it is pretend to become a seed for a wider system which could be used as a citizen oversight tool to bring the people information, not only about what is been done in infrastructure domain, but in every domain of public investment. The system will present detailed info of what are the specific projects that are in execution and also will help the governor to know the progress of those projects

Therefore the project of monitoring the execution of infrastructure projects is another concrete use of the technology in the improvement of governmental duties which proves that the tasks can be done in an easy and clear way. Not just the governor can do a better job but the people can see clearly what and how the things have been doing.

\section{CONCLUSION}

As conclusion, we will like to mention that, even if the efforts are great, there is still a lack of interest from some sectors of government in the process of adopt TICs into the public administrations. Regardless of that, the job must be done to have the tools ready to implement them and push the law to become real and not just a piece of paper.

Right now, we are at the beginning of an attempt to improve democratic process and things are not very clear. There is not a specific model for the implementation of ICT's in the governmental administration, but it doesn't mean we should not try to do it. As I showed in the text there are many positions about the role ICT's should play in the 21-century democracy but what it is for sure is that we are in a very special moment in which the democracy must be re-thought and it is necessary to begin the process of make a research and use them.

There is still a lot of work to do, not only in the theoretical field but also in the development of new ways to create tools that show the people how to use technology to get more involved in political decisions. And that is the important of a multidisciplinary research: it gives a wide perspective not just in the production and development of tools, but also in the way they must be used.

Those projects we have mentioned are a first step for the big goal of develop a whole system to help in the administration of regional government. Those are particular use cases that are being in action; they are not error free but are an important attempt that is continually improved. Particularly, the Geomática Gestión y Optimización de Sistemas group has been a pioneer in the implementation of new technologies in different fields and now is getting involved in offering services to regional political entities.

\section{ACKNOWLEDGMENT}

Thanks to the investigation group Geomática Gestión y Optimización de Sistemas, who finances this project and provides a platform to expand the knowledge of all of the people that works in the group.

\section{REFERENCES}

[1] M. Castells, Comunicación y Poder, Madrid, Spain: Alianza Editorial, 2009, ch. 1, pp. 68-71.

[2] M. Schudson, "Political Communications: History" in International Encyclopedia of Communications, vol. 3, E. Barnouw, Ed. New York: Oxford University Press, 1983. 
[3] T. Christiano. (Fall 2008). Democracy. The Stanford Encyclopedia of Philosophy. [Online] Available: http://plato.stanford.edu/archives/fall2008/entries/democracy/

[4] A. C. B. Garcia, T. C. Tavares, and A. S. Vivacqua, "Enabling Crowd Participation in Govermental Decision-making," Journal of Universal Computing Science, vol. 17, no. 14, pp. 1931-1950, Oct. 2011.

[5] Democracia Real Ya! Manifesto. [Online]. Available: http://www.democraciarealya.es/manifiesto-comun/manifesto-english/

[6] Referendum. Wikipedia, the free Encyclopedia. [Online]. Available: http://en.wikipedia.org/wiki/Referendum

[7] B. Kaufmann. (May 2007). How direct democracy makes Switzerland a better place. [Online]. Available: http://www.telegraph.co.uk/news/1435383/How-direct-democracy-ma kes-Switzerland-a-better-place.html

[8] A. C. Bicharra, F. Pinto, and I. N. Ferraz, "Technology as a new Backbone to Democracy," in IADIS International Conference Web Based Communities 2004, Lisbon, 2004, pp. 215-222.

[9] M. Hilbert, "The Maturing Concept of E-Democracy: From E-Voting and Online Consultations to Democratic Value Out of Jumbled Online Chatter," Journal of Information Technology \& Politics, vol. 6, no. 2, pp. $87-110$

[10] L. Berntzen, and E. Karamagioli, "Regulatory Measures to Support eDemocracy," in 2010 Fourth International Conference on Digital Society, 2010, pp. 311-316

[11] T. Gross, "Technological Support for e-Democracy: History and Perspectives," in Proceedings 11th International Workshop on Database and Expert Systems Applications, 2000, pp. 391-395

[12] The Networked Readiness Index 2010-2011, The Global Information Technology Report 2010-2011, Transformations 2.0, S. Dutta, and I Mia, Eds. Genova, 2011.

[13] Educacióny TIC: algunas estadísticas. Colombia Digital. [Online]. Available:

http://www.colombiadigital.net/opinion/columnistas/rafael-orduz/item /1468-educaci\%C3\%B3n-y-tic-algunas-estad\%C3\%ADsticas.html

[14] Ushahidi. Wikipedia, the free Encyclopedia. [Online]. Available: http://en.wikipedia.org/wiki/Ushahidi

[15] Ushahidi. [Online]. Available: http://ushahidi.com/

[16] Ley 1523 de 2012. (April 2012). Diario Oficial [Online]. Available: http://www.imprenta.gov.co/diariop/diario2.pdf?v_numero=48.411

[17] Centro de Información para el Reporte de Emergencias. [Online]. Available: http://garza.uis.edu.co:8080/emergencia/

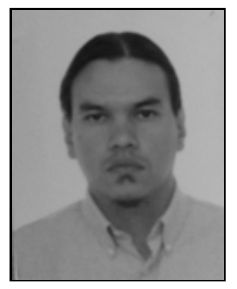

Henry H. Flantrmsky was born in Bucaramanga, Colombia, on July 29th, 1980. With a degree in philosophy from Universidad industrial de Santander, Bucaramanga, Colombia in 2008 and a master degree in logic and philosophy of science from Universidad de Salamanca, Salamanca, Spain in 2011. Right now he is working in his Ph. D. thesis to obtain the doctorate degree also in logic and philosophy of science with Universidad de Salamanca.
Henry has worked in the philosophy faculty as assistant professor and right now is working in the Geomática, Gestión y Optimización de Sistemas research group of the Universidad Industrial de Santander as coordinator in the Cloud Computing project of the group. He has published the paper $L a$ Computación en Nube y el cambio del Paradigma Informático in the journal Pensamiento y Cultura, Bogotá: Universidad de la Sabana, 2011. He is interested in the problems of philosophy, technology and society.

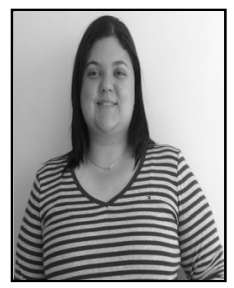

Laura Alejandra Prada Vesga was born in Colombia, on March 11th, 1985. Graduated from Colegio La Quinta del Puente, in 2002. Started to study in Universidad Industrial de Santander, located in Bucaramanga, on 2003 and graduate on 2009, majored in Systems Engineering. Laura is certified on ITIL v3.0 fundaments, and she worked in the División editorial y publicaciones until 2010, located in the university Industrial de Santander, as a systems engineer. Then she start working in the Geomática, Gestión y Optimización de Sistemas research group, as a systems engineer and now she is manager IT. She is interested in the certification processes and how to implement them in the group. Ing. Laura Alejandra Prada Vesga, was part of the logistics committee of the 1er Festival de Cultura Libre that took place in the University Industrial de Santander, on 2012.

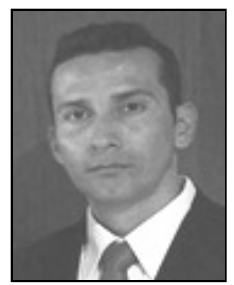

Omar Gallo was born in Bucaramanga, Colombia, on 1974. With a degree in systems engineer from Universidad industrial de Santander, Bucaramanga, Colombia in 2009 and studding a master degree in Informatica in Universidad Industrial de Santander. Omar has worked as a technician in the WIMAX group from 2005 until 2009 and right now work in the Geomática, Gestión y optimización de Sistemas research group in the GIS department and image processing department.

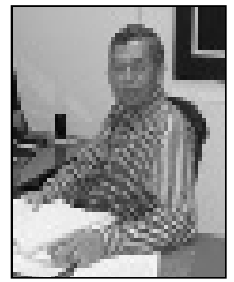

Hernán Porras Díaz was born in Bucaramanga, Colombia, on September 24th, 1995. With a degree in civil engineer from Universidad industrial de Santander, Bucaramanga, Colombia in 1981 and a master degree in Informatica from Universidad Politecnica of Madrid, in 1986, a Ph. D. in Ingenieria Telematica from Universidad Politecnica de Madrid, 1987, and a master degree in Gestion Tecnologica from the Universidad Pontificia Bolivariana, Colombia, 1994. Hernán is the director of the Geomática, Gestión y optimización de Sistemas research group of the Universidad Industrial de Santander, he also is a profesor of the Civil engineer faculty since 1987. He is an experienced professional ontopics related to transport oparation and planning and regional development. He was the in charge of the massive transportation studies in Bucaramanga (Sistema Metrolínea. He was the Environment and Water Secretary of Santander department, director of the Administrative Department of Municipal Planning in Bucaramanga, chief of the planning office in Universidad Industrial de Santander, amoung other administratives positions. 